\title{
RESPON HAMA ULAT BUAH MELON TERHADAP APLIKASI PESTISIDA NABATI BUAH BINTARO (Cerbera manghas L.) PADA BERBAGAI KONSENTRASI
}

\author{
Danang Sudarso Widya Prakoso Joyo Widakdo ${ }^{1 *}$, Shinta Setiadevi ${ }^{1}$ \\ ${ }^{1}$ Program Studi Agribisnis, Politeknik Negeri Banyuwangi
}

Contact Author: danang.sudarso.poliwangi@gmail.com

\section{ABSTRACT}

Hama ulat buah yang sering dijumpai petani melon yaitu serangan hama ulat serta residu pestisida kimiawi yang tinggi. Pemakaian pestisida kimia dengan biaya tinggi, tidak ramah lingkungan sehingga sulit mendapatkan buah melon organik. Pengendalian hama ulat buah dengan menggunakan pestisida nabati menjadi salah satu alternatif, yaitu buah bintaro (Cerbera manghas) yang mengandung senyawa golongan alkaloid yang bersifat toksik, repellent. Hasil penelitian ini menunjukkan bahwa penggunaan pestisida nabati larutan ekstrak buah bintaro mampu mengendalikan populasi hama ulat buah melon. Hal ini dibuktikan dengan semakin menurunnya populasi hama ulat buah melon dengan semakin tingginya konsentrasi pestisida nabati ekstrak buah bintaro.

Kata kunci: buah melon, pestisida nabati, buah bintaro

\section{AGROTECHNOLOGY RESEARCH JOURNAL}

Widakdo DSWPJ, Setiadevi S. 2017. Respon hama ulat buah melon terhadap aplikasi pestisida nabati buah bintaro (Cerbera manghas L.) pada berbagai konsentrasi. Agrotech Res J 1(2): 48-51.

\section{PENDAHULUAN}

Salah satu sentra pertanian khususnya tanaman buah di Propinsi Jawa Timur adalah Kabupaten Banyuwangi. Tanaman buah yang telah dijual di pasar nasional dan menjadi produk unggulan daerah di antaranya alpukat, buah naga, jeruk siam, pepaya, pisang dan semangka, bahkan buah manggis dan melon telah menembus pasar ekspor. Budidaya buah melon memiliki nilai ekonomis yang lebih tinggi dibandingkan buah lain, ditunjang dengan kondisi agroekologi dan agroklimat yang cocok di Banyuwangi. Pemerintah daerah telah membentuk Asosiasi Petani Melon Kabupaten Banyuwangi pada tahun 2009 untuk menanggapi peluang pasar yang ada.

Buah melon telah menjadi komoditas buah unggulan pada Festival Buah Lokal Kabupaten Banyuwangi. Festival yang digelar untuk meningkatkan produktivitas pelaku usaha dan sebagai bukti komitmen Pemerintah Kabupaten Banyuwangi mensejahterakan petani. Namun, petani melon masih menghadapi beberapa kendala dalam budidaya, salah satu kendala tersebut adalah serangan hama ulat yang menyebabkan gagal panen. Produktivitas buah yang rendah dan waktu panen yang lama tentu akan memperkecil rasio keuntungan petani melon.

Salah satu upaya mengendalikan hamaulat buah yang cukup merugikan adalah menggunakan pengendalian kimiawi, tetapi pengendalian secara kimiawi akan menimbulkan dampak negatif dari residu pestisida sintesis. Dampak negatif yang ditimbulkan oleh pestisida sintetis tersebut dapat ditanggulangi dengan menggunakan pestisida alternatif yang lebih efektif, cepat, mudah tergradasi dan mempunyai dampak yang kecil terhadap lingkungan.
Salah satu pestisida alternatif yang berpotensi dalam mengendalikan populasi hama adalah pestisida alami yang berasal dari senyawa kimia tumbuhan. Beberapa tumbuhan diketahui dapat memberi efek mortalitas terhadap hamaserangga sehingga tanaman tersebut dapat digunakan sebagai alternatif insektisida nabati, salah satunya adalah tanaman bintaro (Cerbera manghas).

Penelitian tentang Cerbera manghas membuktikan bahwa buah bintaro sangat berpengaruh terhadap tingkat kematian serangga hama gudang. Buah bintaro C. manghas memberikan efek kematian yang sangat tinggi terhadap kutu beras $S$. oryzae (Coleoptera: Curculionidae), hampir seluruh bagian tanaman bintaro beracun karena mengandung senyawa golongan alkaloid yang bersifat toksik, repellent, dan mempunyai aktivitas penghambat makan terhadap serangga hama gudang (antifeedant) (Guswenrivo 2003).

Penelitian bertujuan mengetahui pengaruh pemberian pestisida nabati buah bintaro terhadap pengendalian hama ulat buah melon dan mencari konsentrasi pestisida nabati optimal yang ditambahkan pada aplikasi pengendalian hama ulat buah melon.

\section{METODE PENELITIAN}

Penelitian ini dilaksanakan di Politeknik Negeri Banyuwangi mulai bulan Mei-Agustus 2017. Alat-alat yang digunakan dalam penelitian antara lain: pisau, saringan, wadah penyimpanan/toples, pinset, timba, polybag, gunting, alat tulis, mixer, sprayer, gelas ukur, pengaduk. Bahan-bahan yang digunakan antara lain: tanaman buah melon, buah bintaro, kertas merang, kertas label, air dalam kemasan.

Penelitian dilaksanakan menggunakan Rancangan Acak Kelompok (RAK) menggunakan larutan ekstrak buah bintaro yang terdiri dari 6 perlakuan, yaitu: kontrol (tanpa larutan ekstrak buah bintaro $/ \mathrm{K}_{0}$ ), penyemprotan 
larutan ekstrak buah bintaro $5 \mathrm{~g} / 100 \mathrm{ml}$ air $\left(\mathrm{K}_{1}\right)$, penyemprotan larutan ekstrak buah bintaro $10 \mathrm{~g} / 100 \mathrm{ml}$ air $\left(\mathrm{K}_{2}\right)$, penyemprotan larutan ekstrak buah bintaro 15 $\mathrm{g} / 100 \mathrm{ml}$ air $\left(\mathrm{K}_{3}\right)$, penyemprotan larutan ekstrak buah bintaro $20 \mathrm{~g} / 100 \mathrm{ml}$ air $\left(\mathrm{K}_{4}\right)$ dan penyemprotan larutan ekstrak buah bintaro $25 \mathrm{~g} / 100 \mathrm{ml}$ air $\left(\mathrm{K}_{5}\right)$.

\section{HASIL DAN PEMBAHASAN}

Hasil analisis ragam terhadap populasi hama ulat buah disajikan pada Tabel 1 .

Tabel 1 Analisis ragam terhadap populasi hama ulat buah yang dipengaruhi konsentrasi pestisida nabati larutan ekstrak buah bintaro

\begin{tabular}{lr}
\hline Populasi hama ulat buah & \multicolumn{1}{c}{ F-hitung } \\
\hline $60 \mathrm{hst}($ awal) & $20,871^{\mathrm{Ns}}$ \\
$67 \mathrm{hst}$ & $17,750^{* *}$ \\
$74 \mathrm{hst}$ & $49,500^{* *}$ \\
$81 \mathrm{hst}$ & $38,696^{* *}$ \\
$88 \mathrm{hst}$ & $68,187^{* *}$ \\
$95 \mathrm{hst}$ & $107,167^{* *}$ \\
\hline
\end{tabular}

Keterangan $:^{* *}:$ berbeda sangat nyata, ${ }^{*}:$ berbeda nyata ns : berbeda tidak nyata
Pengujian terhadap populasi hama ulat buah menggunakan analisis ragam (Analysis of Variance) dan dilanjutkan dengan uji jarak berganda Duncan (Duncan Multiple Range Test), sedangkan Pengujian terhadap mortalitas hama ulat buah menggunakan analisis $\mathrm{LC}_{50}$ (Lethal Concentrate 50) dan $\mathrm{LT}_{50}$ (Lethal Time 50).

Hasil analisis ragam menunjukkan bahwa perlakuan aplikasi pestisida nabati buah bintaro berpengaruh sangat nyata terhadap populasi hama ulat buah pada $67,74,81,88$ dan 95 hst, sedangkan pada pengamatan awal yaitu $60 \mathrm{hst}$ tidak berpengaruh nyata. Rata-rata populasi hama ulat buah yang dipengaruhi perlakuan aplikasi pestisida nabati buah bintaro pada berbagai dosis disajikan pada Tabel 2 .

Aplikasi pestisida nabati buah bintaro dosis $25 \mathrm{~g} / 10$ $\mathrm{ml}$ air (K5) menghasilkan populasi hama ulat buah terkecil dengan rata-rata 10,33 buah (67 hst), 8,33 buah (74 hst), 7,33 buah (81 hst), 4,33 buah (88 hst) dan 1,67 buah (95 hst).

Tabel 2 Rata-rata populasi hama ulat daun yang dipengaruhi perlakuan aplikasi pestisida nabati buah bintaro pada berbagai dosis

\begin{tabular}{|c|c|c|c|c|c|c|c|c|}
\hline \multirow{2}{*}{$\begin{array}{l}\text { Dosis pestisida nabati buah } \\
\text { bintaro }\end{array}$} & \multicolumn{8}{|c|}{ Rata-rata Populasi Hama Ulat Daun } \\
\hline & $67 \mathrm{hst}$ & $74 \mathrm{hst}$ & $81 \mathrm{hst}$ & & & hst & $95 \mathrm{~h}$ & \\
\hline $\mathrm{K} 0$ (0 g/10 ml air) & $16,33 \mathrm{D}$ & $16,33 \quad D$ & 16,33 & D & 15,33 & $\mathrm{~d}$ & 14,33 & $\mathrm{~d}$ \\
\hline K1 (5 g/10 ml air) & $15,00 \mathrm{Cd}$ & 14,33 & 13,67 & $\mathrm{~cd}$ & 12,00 & c & 10,33 & c \\
\hline $\mathrm{K} 2(10 \mathrm{~g} / 10 \mathrm{ml}$ air $)$ & $14,33 \mathrm{Bcd}$ & $14,00 \mathrm{Cd}$ & 13,00 & C & 11,00 & c & 9,33 & c \\
\hline K3 (15 g/10 ml air) & $13,33 \quad B c$ & 13,00 & 12,00 & $\mathrm{bc}$ & 9,33 & bc & 7,33 & bc \\
\hline $\mathrm{K} 4(20 \mathrm{~g} / 10 \mathrm{ml}$ air $)$ & $11,67 \mathrm{Ab}$ & 10,67 & 9,33 & $a b$ & 7,00 & $a b$ & 4,67 & $a b$ \\
\hline $\mathrm{K} 5$ (25 g/10 ml air) & 10,33 & 8,33 & 7,33 & a & 4,33 & a & 1,67 & a \\
\hline
\end{tabular}

Keterangan :Rata-rata yang diikuti notasi yang sama pada kolom yang sama menunjukkan berbeda tidak nyata pada uji jarak berganda Duncan taraf $5 \%$.

Menurut Thamrin et al. (2007), selain memiliki senyawa aktif utama dalam ekstrak tumbuhan juga terdapat senyawa lain yang keberadaannya dapat meningkatkan aktivitas ekstrak secara keseluruhan (sinergi). Dalam kaitannya dengan aktivitas makan, serangga dapat mengenali senyawa-senyawa asing dalam makanannya dalam konsentrasi tertentu dan akan merespon atas kehadiran senyawa tersebut dalam makanannya. Hal ini sesuai dengan pendapat Yunia (2006) yang menyatakan bahwa kehadiran senyawa-senyawa yang belum dikenal (foreign compounds) dapat mengakibatkan penolakan pada serangga. Penggunaan ekstrak tumbuhan sebagai salah satu sumber pestisida nabati didasarkan atas pemikiran bahwa terdapat mekanisme pertahanan dari tumbuhan. Salah satu senyawa yang dihasilkan oleh tumbuhan yaitu senyawa metabolik sekunder yang bersifat penolak (repellent), penghambat makan (antifeedant/feeding deterrent), penghambat perkembangan dan peneluran (oviposition repellent/deterrent) dan sebagai bahan kimia yang mematikan serangga dengan cepat.
Hasil pengujian $\mathrm{LC}_{50}$ dengan perlakuan pestisida nabati larutan ekstrak buah bintaro disajikan pada gambar berikut :
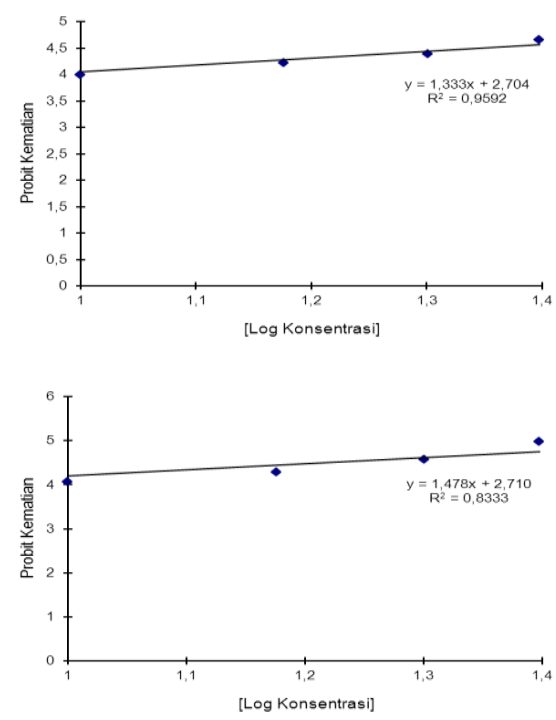

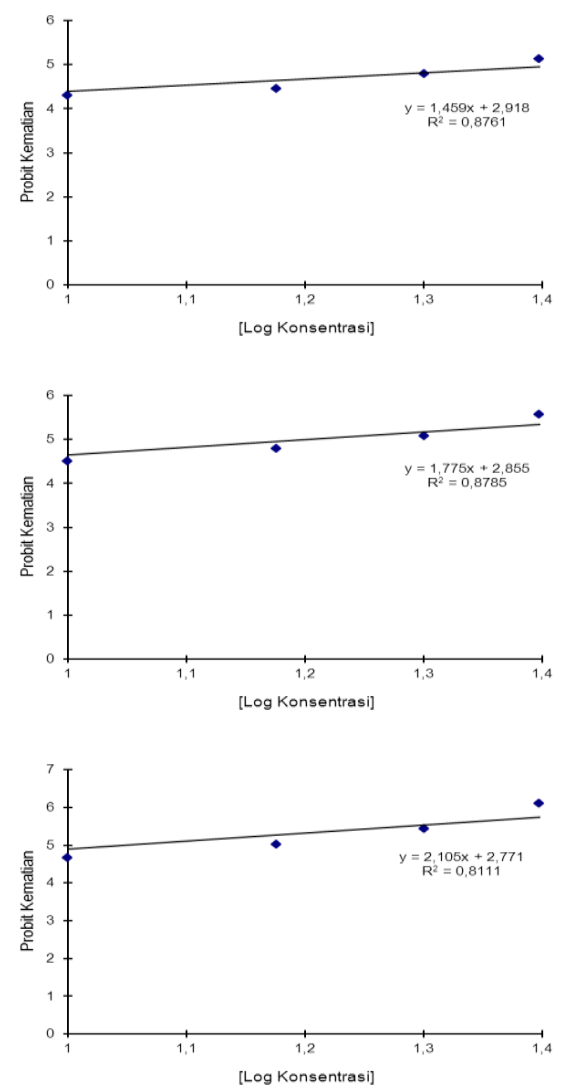

Gambar 1 Hubungan konsentrasi pestisida nabati larutan ekstrak buah bintaro pada hari ke-67, 74, 81, 88 dan 95 dengan probit kematian hama ulat buah

Berdasarkan gambar di atas, hubungan antara log konsentrasi dan nilai probit terhadap mortalitas ulat buah, menunjukkan bahwa semakin besar konsentrasi, maka probit kematian hama ulat buah akan semakin meningkat.

Hasil pengujian $\mathrm{LT}_{50}$ dengan perlakuan pestisida nabati larutan ekstrak buah bintaro disajikan pada gambar berikut:
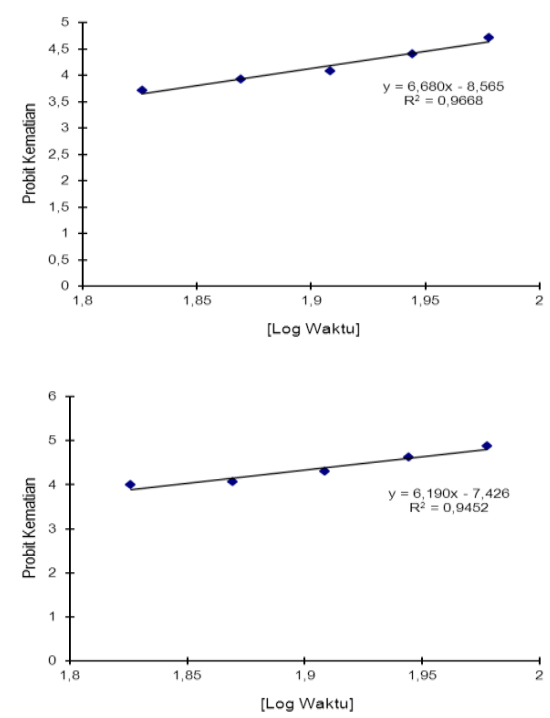
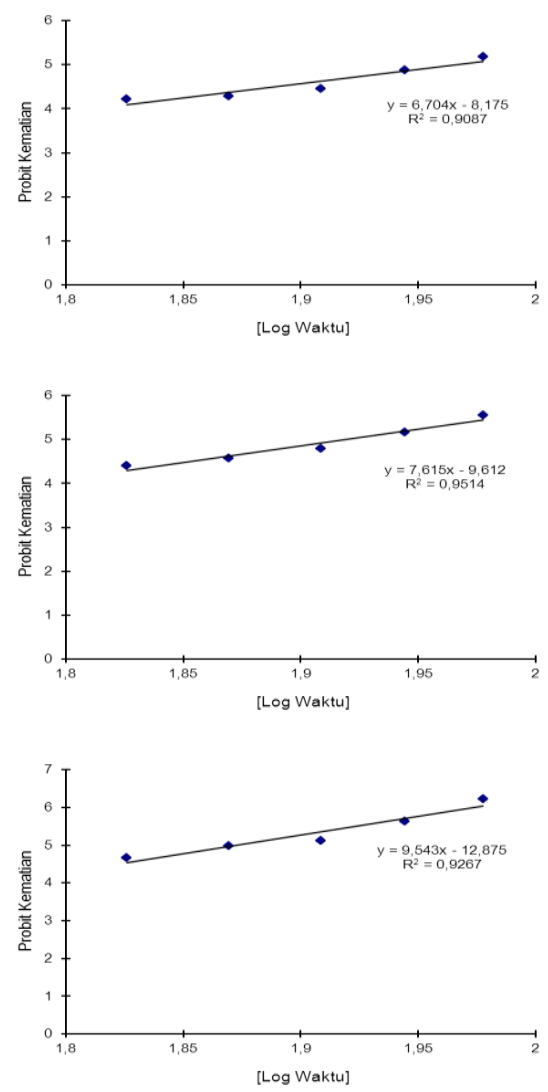

Gambar 2 Hubungan lama waktu aplikasi pestisida nabati larutan ekstrak buah bintaro pada konsentrasi 25 $\mathrm{g} / 10 \mathrm{ml}$ air dengan probit kematian hama ulat buah

Berdasarkan gambar di atas, hubungan antara log waktu dan nilai probit terhadap mortalitas ulat buah, menunjukkan bahwa semakin lama waktu, maka probit kematian hama ulat buah akan semakin meningkat.

Secara umum pestisida nabati mempunyai kelebihan dan kelemahan. Dalam suatu ekstrak tumbuhan, selain beberapa senyawa aktif utama biasanya juga terdapat banyak senyawa lain yang kurang aktif, namun keberadaannya dapat meningkatkan aktivitas ekstrak secara keseluruhan (sinergi). Serangga tidak mudah menjadi resisten terhadap ekstrak tumbuhan dengan beberapa bahan aktif, karena kemampuan serangga untuk membentuk sistem pertahanan terhadap beberapa senyawa yang berbeda sekaligus lebih kecil daripada terhadap senyawa pestisida tunggal. Selain itu, banyak senyawa tumbuhan yang memiliki cara kerja yang berbeda dengan pestisida sintetik yang umum digunakan saat ini, sehingga kemungkinan terjadinya resistensi silang cukup kecil. Namun pestisida nabati mempunyai kelemahan yaitu persistensinya yang pendek. Pestisida nabati merupakan bahan yang mudah terurai di alam sehingga tidak dikhawatirkan akan menimbulkan bahaya residu besar. Keadaan tersebut juga dapat menekan peluang jasad bukan sasaran terkena residu. Persistensi pestisida alami yang singkat kurang menguntungkan dari segi ekonomi, karena pada tingkat populasi yang tinggi, untuk mencapai keefektifan pengendalian yang maksimum diperlukan aplikasi berulang-ulang. Namun sifat tersebut memungkinkan pestisida nabati dapat digunakan beberapa saat 
menjelang panen (Prijono, 1999). Selain itu pestisida nabati tidak tahan disimpan dalam waktu yang lama karena senyawanya yang mudah terurai sehingga semakin lama disimpan akan menurunkan toksisitasnya (Amelia dan Supriyadi 2001).

\section{KESIMPULAN DAN SARAN}

Penggunaan pestisida nabati larutan ekstrak buah bintaro mampu mengendalikan populasi hama ulat buah melon. Hal ini dibuktikan dengan semakin menurunnya populasi hama ulat buah melon dengan semakin tingginya konsentrasi pestisida nabati ekstrak buah bintaro.

Terdapat beberapa konsentrasi optimal pestisida nabati larutan ekstrak buah bintaro berdasarkan lamanya pengamatan, yaitu $52,75 \mathrm{~g} / 10 \mathrm{ml}$ air (hari ke67), 35,42 g/10 ml air (hari ke-74), 26,71 g/10 ml air (hari ke-81), 16,15 g/10 ml air (hari ke-88) dan 11,46 $\mathrm{g} / 10 \mathrm{ml}$ air (hari ke-95). Sedangkan berdasarkan lama waktunya konsentrasi $5 \mathrm{~g} / 10 \mathrm{ml}$ air optimal pada 107,34 hari, $10 \mathrm{~g} / 10 \mathrm{ml}$ air optimal pada 101,73 hari, $15 \mathrm{~g} / 10 \mathrm{ml}$ air optimal pada 92,27 hari, $20 \mathrm{~g} / 10 \mathrm{ml}$ air optimal pada 83,17 hari dan $25 \mathrm{~g} / 10 \mathrm{ml}$ air optimal pada 74,65 hari.

\section{REFERENSI}

Dewi IR. 2007. Prospek insektisida yang berasal dari tumbuhan untuk menanggulangi organisme pengganggu tanaman. Bandung: UNPAD.

Guswenrivo I, Tarmadi D, Yusuf S. 2013. Aktivitas insektisida ekstrak buah bintaro (Cerbera manghas) terhadap kutu beras Sitophilus oryzae (Coleoptera:Curculionidae) (Insecticide Activity of Cerbera manghas Fruit Exstract to Sitophilus oryzae(Coleoptera: Curculionidae). Jurnal IImu dan Teknologi Kayu Tropis. Vol. 11 (1).

Hewindati, Yuni Tri dkk. 2006. Hortikultura. Jakarta: Universitas Terbuka.

Kardinan A. 2001. Pestisida nabati: ramuan dan aplikasi. Jakarta: Penebar Swadaya.

Karlina NKN. 2014. Keragaman dan dinamika populasi lalat buah (Diptera: Tephritidae) yang menyerang tanaman buah-buahan di Bali. [Tesis] Denpasar: Universitas Udayana.

Kartimi. 2015. Pemanfaatan buah bintaro sebagai biopestisida dalam penanggulangan hama pada tanaman padi dikawasan pesisir Desa Bandengan Kabupaten Cirebon. Prosiding Seminar Nasional Pendidikan Biologi 2015, yang diselenggarakan oleh Prodi Pendidikan Biologi FKIP Universitas Muhammadiyah Malang, Tema: "Peran Biologi dan Pendidikan Biologi dalam menyiapkan Generasi Unggul dan Berdaya Saing Global", Malang, 21 Maret 2015.

Purwani KI, Wijayawati L, Nurhatika S, Sa N A, Diyah, Arifiyanto A. 2014. Bintaro (Cerbera odollam) leaf extract as a potential biological pest control toward spodopteralitura F. Mortality. Journal of Applied Environmental and Biological Sciences. 4(4) 18-23.

Siswanto. 2010. Meningkatkan kadar gula buah melon. Surabaya: UPN "Veteran Jawa Timur". ISSN: 978602-9372-00-7

Sudjianto U dan Krestiani V. 2009. Studi pemulsaan dan Posisi NPK pada hasil buah melon (Cucumis melo L). Jurnal Sains dan Teknologi. 2 (2).

Tarmadi DAH, Prianto, GuswenrivolT, Kartika S, Yusuf. 2007. Pengaruh Ekstrak Bintaro (Cerbera odollam Gaertn.) dan Kecubung (Brugmansia candida Pers) terhadap rayap tanah Captotermes sp. J Trop. Wood Scie.\& Tech. 5(1).

Untung K. 1993. Pengantar pengelolaan hama terpadu. Yogyakarta: Gadjah Mada University Press.

Utami S. 2010. Aktivitas insektisida bintaro (Cerbera odollam Gaertn) terhadap hama Eurema spp. pada skala laboratorium. Jurnal Penelitian Hutan Tanaman 7(4): 211-220.

Wudianto R. 2001. Petunjuk Penggunaan Pestisida. Jakarta : Penebar Swadaya.

Yan XF, Tao, PingTW. 2011. Chemical and bioactivity of mangrove plants in the genus cerbera. Journal of Guangxi Academy of Science. 2011-01. 